\title{
„A přišel ti naproti?": dohled rodičů jako neviditelná bariéra prostorového chování jejich dcer ve vzdálených univerzitních městech ${ }^{1}$
}

\author{
"And Did He Come to Pick You Up?": Parental Control as an \\ Invisible Barrier to the Spatial Behaviour of Daughters in Distant \\ University Cities
}

Robert Osman, Jana Jíchová

\begin{abstract}
Research on perceptions of security has long focused on exploring fear for oneself, but fear for other person, so-called altruistic fear, which can contribute significantly to the overall perception of security, is equally important. Fear for others is also related to the need for surveillance and control over those for whom we worry. This article focuses on the importance of transferred, spatially absent parental control for the perception of fear for daughters who moved from a small municipality to a large, distant university city. Through semi-structured interviews with female first and second year college students, we examine how their feelings of safety and danger in the new environment transformed during their transition to university, how parents approached their leaving home and how they communicated with their daughters, and how the parents continued to supervise them despite the spatial divide. Our analysis shows the different forms that the relationship between parental control and their daughter's fear can take, and how fear for oneself can be interwoven with fear for others.
\end{abstract}

KEY WORDS Surveillance/control, safety, altruistic fear, women, parents, invisibility

\section{Úvod}

Téma strachu je výzkumníky a výzkumnicemi studováno již dlouhodobě a lze najít řadu konceptů snažících se vysvětlit důvody strachu, strachu z kriminality, nižšího pocitu bezpečí, pocitu nebezpečí. Zdroje strachu jsou hledány jak v individuálních vlastnostech, charakteristikách a zkušenostech, tak v kontextu sociálního a fyzického prostředí, ve kterém žijeme, pohybujeme se, pracujeme, provozujeme různé aktivity, a nelze opomenout ani vnější vlivy, nap̌r. roli médií a jejich způsobů prezentace bezpečí a nebezpečí (srovnej Hale 1996; Vozmediano et al. 2017). Jinou možností, jak lze nahlížet na zdroje strachu, je jejich časová a prostorová (ne)př́tomnost v určité situaci, tedy určitá (ne)viditelnost. Lze je rozlišit na ty,

Sociální studia / Social Studies 1/2019. S. 103-122. ISSN 1214-813X.

1 Příspěvek vznikl s finanční podporou Grantové agentury České republiky GAČR jako součást projektu č. 16-02242S „Prostorové vzorce kriminality a percepce bezpečí v Česku“ a dlouhodobého koncepčního rozvoje výzkumné organizace RVO: 68145535. 
které jsou časově i prostorově přítomné, např́klad charakteristiky prostoru, charakteristiky času, vlastnosti konkrétních situací, ale i individuální vlastnosti, charakteristiky a zkušenosti každé, její aktuální fyzický a psychický stav apod. Tyto bývají častým předmětem zájmu výzkumníků a výzkumnic (Hale 1996; Vanderveen 2006). Druhá skupina představuje ty, které jsou př́tomné pouze časově a do prostoru či aktuální situace jsou pouze určitým způsobem přenesené. Lze sem zařadit média, urbánní legendy a nálepky míst, vliv rodiny, legislativy apod. (Ferraro 1995 aj.).

Právě přenesený strach, na první pohled neviditelný, ale přesto časově přítomný, představuje oblast, která nás $\mathrm{v}$ tomto textu zajímá především. Specificky se pak zaměřujeme na strach o druhé, tzv. altruistický strach (Warr 1992), na to, jak je tento strach předáván i jak ovlivňuje ty, na které je přenesen. V tomto kontextu můžeme mluvit o souvislosti s dohledem, skrze který může být strach vytvářen, přenášen, udržován i zvyšován. Strach o druhé může vyvolat potřebu dohližet na ty, o které se bojíme, mít o nich přehled, mít je pod kontrolou. Tento strach bývá směřován na členy rodiny, na příbuzné, blízké i vzdálenější přátele, vztahuje se ke krátkodobým situacím, spojeným s návratem domů - cestou do školy, do práce, ale i dlouhodobějším pobytům - na dovolené, na stážích, na vysoké škole atp. (Warr a Ellison 2000; Snedker 2006; Drakulich 2014; Foster et al. 2014). V př́ípadě tohoto př́íspěvku jsme proto téma zúžili na specifický dohled rodičovský. Ten navíc zkoumáme na specifické skupině osob, u které $\mathrm{v}$ nedávné době došlo $\mathrm{k}$ významné změně $\mathrm{v}$ možnostech př́mého dohledu rodičů. Př́spěvek se tak věnuje skupině mladých žen - studentek, dcer, které změnily své prostředí, protože se vydaly studovat vysokou školu do „velkého“ univerzitního města, kde se ocitly mimo dohled svých rodičů. Náš primární zájem se tak soustředí na tento rodičovský dohled, který je přenesený, určitým způsobem zprostředkovaný, a tedy neviditelný, nicméně stále prítomný ve sžívání se jejich dcer s novým, velkým a neznámým městem. Jinými slovy se předkládaný př́ispěvek věnuje mnohovrstevnatému vztahu mezi (prostorově i sociálně) přeneseným dohledem nad druhými a jejich strachem z prostoru, a to $\mathrm{v}$ konkrétní zkušenosti studentek prvního a druhého ročníku vysokých škol pocházejících z populačně malých obcí. Právě kontrast mezi populačně malou obcí a velkým univerzitním městem a vnímáním jejich bezpečnosti představuje nosný kontext celého výzkumu, který je vhodný doplnit i o pohled statistik kriminality. Na jednu stranu je v České republice zřejmá diferenciace mezi menšími obcemi s nízkou úrovní kriminality a krajskými městy s vy̌šśí úrovní kriminality, na stranu druhou nelze opominout, že se zde či obecně v rámci středoevropského prostoru stále jedná o velmi nízkou úroveň kriminality, např. př́i porovnání se západními zeměmi (Gruszczynska a Gruszczynski 2005 aj.). ${ }^{2}$ Pohled statistik ovšem ne vždy vypovídá o vnímání bezpečnosti. V kontextu středoevropského prostoru vývoj pohledu na bezpečnost a dohled ve městě shrnují Siebel a Wehrheim (2006). Upozorňují na existenci nových hradeb v současné společnosti, hradeb, které ve středověku chránily města před nebezpečím zvenku a které v současnosti existují třeba ve formě tzv. gated communities, oplocených rezidenčních areálů, které často

2 Tento pohled je do jisté míry zjednodušující, úroveň kriminality je nejen vhodnější měřit specifickými měrami druhů kriminality či přímo jednotlivých trestných činů, zároveň je důležitý kontext kriminality, odlišná legislativní nastavení zemí, jejich historický vývoj, společnost apod. Jelikož se ale nejedná o hlavní téma našeho článku, tak jej nerozebíráme dopodrobna. 
mají vlastní bezpečnostní služby a/či kamerové systémy. Stejně tak jsou „,pod dohledem“ i další prostory, veřejné, poloveřejné i soukromé, at’ už nákupní centra, náměstí, nádraží, restaurace, obchody, přičemž se liší, kdo se dívá, zda policejní složky, soukromé agentury či někdo jiný. Liší se také to, komu je věnována větší pozornost. Ne všechny prostory jsou určeny pro všechny. Nákupní centra mají své řády, stejně tak veřejné prostory. Př́ikladem je vyhláška upravující konzumaci alkoholu, která je např. v rámci Prahy regulována na stovkách míst. Dalším příkladem jsou cílené restrikce proti osobám bez přístřeší v centru Prahy, na které je i podle názorů odborníků cíleně směřována pozornost a jsou postihovány (více Temelová et al. 2017).

Je zřejmé, že by bylo nemožné a pravděpodobně i nepř́liš produktivní pokoušet se oddělovat jeden zdroj strachu od druhého. Dohled rodičů, strach přátel, zkušenosti známých, mediální zprostředkování, zpravodajství či systémy vzdělávání mohou nabývat významů nejrůzněji propletených a kombinovaných zdrojů strachu. Naším zájmem tak není očišt’ovat (purifikovat) přenesený dohled rodičů od ostatních zdrojů strachu z prostoru a popisovat, které konkrétní pocity strachu jsou vyvolány přeneseným dohledem rodičů. Spíše chceme ukázat, že i přenesený dohled rodičů hraje ve vnímání neznámého prostoru jejich dcerami svou úlohu a že tato úloha ovlivňuje jejich pocit bezpečí v novém městě. Naše hlavní výzkumná otázka proto zní: jakým způsobem (prostorové i sociální) přenášení dohledu rodičů ovlivňuje strach z prostoru jejich dcer?

\section{Dohled jako strach o druhé}

Dlouhodobě se výzkumy strachu primárně zaměřovaly na osobní strach, tedy strach o sebe sama, zkoumaly důvody tohoto strachu, místa strachu, odlišnosti vázané na charakteristiky a vlastnosti jednotlivců apod. Až od počátku 90. let 20. století se objevují studie rozlišující mezi strachem o sebe a strachem o druhé (Madriz 1997) i studie, které se cíleně zaměřují na hledání odlišností těchto dvou strachů (Warr 1992; Warr a Ellison 2000). Právě Mark Warr (1992) přichází s termínem altruistický strach (altruistic fear) a rozvíjí myšlenku o jeho důležitosti v kontextu celkového pocitu bezpečí. Karin A. Snedker (2006) navazuje na jeho myšlenku, ale přichází s jiným termínem - zástupným strachem (vicarious fear), který podle ní lépe vystihuje podmínky strachu o druhé. V pravém významu by totiž altruistický mělo znamenat nesobecký, sebeobětující, nepřinášející vlastní zisk. V případě strachu o blízké druhé lze však spíše tvrdit, že se altruistické chování obávajících prolíná s jejich osobními zájmy (Snedker 2006).

Altruistický/zástupný strach se zvláště umocňuje v rámci rodinných či příbuzenských vztahů. Jak dokládá mnoho výzkumů, jsou to typicky rodiče, kteří se obávají o své děti, a často jejich strach o ně dokonce přesahuje i jejich strach o sebe sama (Warr a Ellison 2000; Snedker 2006; Drakulich 2014). S rostoucím věkem dětí pocit strachu rodičů o ně sice klesá, přičemž největší bývá u čerstvých rodičů (Warr a Ellison 2000; Tulloch 2004), nicméně nemizí zcela, a rodiče se tak mohou obávat a obávají se i o své dospělé děti (Heber 2009). Zároveň výzkumy ukazují, že nejsou př́liš velké rozdíly mezi intenzitou strachu mezi otci a matkami (Warr a Ellison 2000; Snedker 2006; Heber 2009; Vozmediano et al. 2017), co ale podstatné je, tak o koho se bojí. Rodiče, nehledě na to, zda se jedná o matky či otce, se totiž více bojí 
o své dcery než o své syny (Heber 2009; Foster et al. 2014; Vozmediano et al. 2017). Zvýšený strach o dívky lze interpretovat v kontextu větší zranitelnosti a strachu z jejich sexuálního obtěžování či sexuálního zneužití. Výzkumy přitom dokládají, že strach žen ze znásilnění často zvyšuje strach ze všech ostatních trestných činů, a významně tak ovlivňuje jejich pocit bezpečí (Stanko 1990; Ferraro 1995; Pain 1997).

Strach rodičů o jejich děti se ale neprojevuje pouze na pocitovaném strachu rodičů, ovlivňuje i strach samotných dětí. May et al. (2002) prŕmo upozorňují, že tím, že se rodiče o své děti bojí, je zároveň mohou učit bát se, a v mnoha situacích tak jejich strach přímo vytvářet. ${ }^{3}$ Rodiče tak svým chováním, komentáři, radami, př́kazy i celkovým přístupem mohou přiřazovat negativní významy nejen konkrétním místům, ale i specifickým lidem, skupinám lidí, situacím či způsobům chování. Příkladem může být strach rodičů z neznámých/ cizinců, kvůli kterým je omezována samostatná mobilita dětí (Foster et al. 2014; Crawford et al. 2017). Děti vedené k vidění všech dospělých jako potenciálně podezřelých pak mohou být v dospělosti dokonce obtížně zapojitelní do jakéhokoliv občanského/sociálního života (Glassner 2009). Dále mohou přebírat některé návyky chování svých rodičů, aniž k tomu existuje jakékoliv racionální zdůvodnění. Takovéto vzorce chování pak mohou přetrvávat až do dospělosti a ovlivňovat, jak se lidé cítí při pohybu městem, zda, kde a čeho se obávají. ${ }^{4}$

Strach rodičů může být spojen se specifickými situacemi. U mladších dětí se může jednat např́iklad jen o hraní si na hřištích či samostatnou cestu do školy. Výzkumy nicméně dokládají, že neustále klesající nezávislý samostatný pohyb dětí po městě souvisí s obavami a strachy rodičů z konfrontace svých dětí s neznámými situacemi, neznámými lidmi, respektive s potenciálními trestnými činy (únos, sexuální obtěžování, sexuální zneužití apod.) (Foster et al. 2014). U starších, dospívajících dětí jsou z pohledu rodičů jako rizikové situace nejčastěji vnímány př́ípady, kdy se jejich děti vracejí pozdě v noci, vracejí se samy domů, nebo když se pohybují po městě ve dne ve „špatných“ částech města, po „nebezpečných“ místech (Foster et al. 2014). Určitý posun ve vnímání rizikovosti a exponovanosti specifických situacích je logický vzhledem k rostoucímu věku dětí, jejichž aktivity se proměňují, v souvislosti s nimi i denní režim, pohyb po městě, sociální vztahy apod. Posun je pak zřejmý i v dospělosti. Anita Heber (2009) nabízí konkrétní situace, které zmínili její (již dospělí) komunikační partneři a partnerky, jimiž rodiče pod vlivem zpráv z médií odrazovali své děti od cestování do zemí, kde došlo k teroristickým útokům, či se strachovali kvůli bydlišti svých vnoučat ve městech s velkým počtem vloupání do bytů.

U rodičů se projevuje strach z neznámého, co by se všechno mohlo jejich dětem, a především pak jejich dcerám stát, a o to víc v situacích, když ztrácí přehled, kde přesně jejich děti jsou, s kým jsou, kdy se vrátí, koho tam mohou potkat, když jim nemohou pomoci, kdyby se něco stalo. Lze tak hovořit o proměně strachu v návaznosti na ztrátu dohledu, který byl dříve relativně př́mý, nezprostředkovaný, realizovaný v kontextu konkrétních situací např. formou doprovodu do školy, kontroly z lavičky na hřišti, kontroly času příchodu a který je postupem

3 Výzkumy rovněž dokládají, že dospívající, jejichž rodiče je více kontrolovali, byli bázlivější, než ti s méně kontrolujícími rodiči (May et al. 2002; De Groof 2008; Podaná a Krulichová 2018).

4 Na stranu druhou je velmi důležitý vztah s rodiči. Nefungující vztahy či větší izolace vede naopak k většímu pocitu strachu (Wallace a May 2005). 
času nahrazován přeneseným dohledem ve formě rodičovských varování před určitými situacemi, doporučeními, co mají a nemají jejich děti dělat, atp. (Warr a Ellison 2000; Snedker 2006). Rodiče tak svým dospívajícím dětem doporučují strategie jako brát si mobilní telefon, využívat taxi místo nočních spojů městské dopravy, vyhýbat se místům s potenciálním nebezpečím, nechodit do budov, kde nikoho neznají, nechodit sami atp. (Snedker 2006; Heber 2009). Obdobně ale radili i blízkým přátelům či př́buzným, které rovněž žádali o zavolání po př́ijezdu domů či využívání taxi služby (Heber 2009). Specificky pak je v literatuře reflektován strach mužů o své partnerky, včetně např. rad o nenošení krátkých sukní, velkých výstřihů a vyzývavého oblečení, aby zbytečně neprovokovaly své okolí (Snedker 2006).

Dohled rodičů je dětmi velmi silně reflektován, uvědomují si ho (Crawford et al. 2017), zvláště pak v př́ípadě dívek, u kterých je častější (De Groof 2008; Podaná a Krulichová 2018). Samotné reakce dětí mohou být velmi různorodé a silně ovlivněné vztahy v rodině, individualitou, vlastnostmi, věkem, pohlavím a dalšími charakteristikami dětí, sociálním kolektivem, ve kterém se pohybují, ale i tím, kdo tento dohled vykonává. Škála reakcí pak zahrnuje akceptování dohledu, jeho vítání a uzpůsobování svého chování, ale i jeho zlehčování, úmyslného nedodržování, ztěžování dohledu apod. (Tulloch 2004; Crawford et al. 2017). U dívek je zdůrazňováno, že důslednější organizace jejich aktivit rodiči vede $\mathrm{k}$ jejich nižšímu pocitu strachu (De Groof 2008). Větší dohled, varování a kontrola ale může představovat i utužení sociální kontroly nad životem žen skrze větši restrikce jejich svobody, např. změnu chování, způsob oblékání, pohyb po veřejných místech atp. (Madriz 1997). Konkrétní strategie žen, pomocí kterých se snaží předcházet pocitu strachu v českém kontextu, představují ve své studii např́klad Robert Osman a Jana Jíchová (2019).

Souhrnně lze říci, že dohled rodičů se významně projevuje nejen na pocit’ovaném strachu jejich dětí, ale má konkrétní důsledky i např. v podobě změny prostorového chování, způsobu vystupování, stylu oblékání apod. Ještě specifičtější je situace $\mathrm{v}$ př́ípadě dcer, které jednak bývají pod větším dohledem ze strany rodičů (Heber 2009; Vozmediano et al. 2017), a zároveň si samy tento dohled uvědomují (De Groof 2008; Podaná a Krulichová 2018). Co se tedy stane, pokud rodiče ztratí svůj prŕmý dohled, když dojde k přestěhování jejich dcer, k odchodu z jejich dohledu? Jak se konkrétně na životě dcer projevuje dohled rodičŭ, když se z něj stane dohled pouze přenesený, zprostředkovaný? Jakým způsobem dochází k tomuto přenášení či zprostředkování dohledu? Snaží se je rodiče i nadále kontrolovat? Jaké prostředky volí k této kontrole na dálku? Pomocí kterých nástrojů rodiče kontrolují své dcery? Jakým způsobem to jejich dcery reflektují? Jinými slovy, jakým způsobem se strach o dcery přenáší do jejich strachu o sebe sama? To jsou jen př́klady otázek, na které se př́spěvek snaží odpovědět.

\section{Metodika}

Článek je založen na výzkumu, který proběhl v letech 2016 a 2017 a soustředil se na zkoumání pocitu bezpečí u vysokoškolských studentek. Cíleně jsme studovanou populaci v mnoha ohledech zúžili, jednak na ženy, které podle výsledkủ řady výzkumů pocit bezpečí reflektují citlivěji než jiné skupiny, např. muži. Dále jsme vzorek zúžili pouze na studentky, specificky pak na vysokoškolské studentky, které se v nedávné době (12-18 měsíců) přestěhovaly do „nového“, populačně velkého univerzitního města. Tato skupina byla zvolena záměrně, 
protože zachycuje specifickou fázi života spojenou s výraznými změnami. Studentky se stěhují do nového města, nastupují do nové školy, seznamují se s novými spolužáky, mění se jejich denní aktivity, pohybují se novým prostorem. Stále poměrně širokou skupinu vysokoškolských studentek jsme dále zúžili na ty pocházející z populačně menších obcí, studující v prvním či maximálně druhém ročníku vysoké školy (ve velkých univerzitních městech: Praha, Brno, Ostrava, Olomouc) a dále pak pouze na ty, které před př́́chodem na vysokou školu nežily v žádném větším městě. Vedle samotného vymezení zájmové skupiny studovaných osob měla zvolená kritéria výběru za cíl zabezpečit, aby se jednalo o studentky, které na jednu stranu mají s univerzitním městem již dostatek zkušeností, ale na druhou stranu, aby si ještě dokázaly vzpomenout na situaci těsně po svém př́chodu do univerzitního města. Kombinace těchto kritérií by tak měla zajistit, že naše komunikační partnerky budou schopné reflektovat, jak se vyvíjelo jejich vnímání a prožívání strachu po př́íchodu do „nového“ města.

Takto úzce zaměřená kritéria na jednu stranu zabezpečila relativní homogenitu zkušenosti komunikačních partnerek, na druhou stranu velmi znesnadnila způsob jejich vyhledávání. Kombinace omezení na ženy, studentky vysokých škol, studující ve velkých (minimálně krajských) městech České republiky, studující pouze v 1. nebo 2. ročníku, navíc pocházející $\mathrm{z}$ menších obcí, které ještě $\mathrm{k}$ tomu neměly předchozí zkušenost $\mathrm{s}$ životem ve větším městě, se ukázala jako velmi př́sná. I $\mathrm{z}$ toho důvodu bylo přistoupeno $\mathrm{k}$ využití vícero metod vyhledávání vhodných komunikačních partnerek. Ty byly nalezeny prostřednictvím vlastní sítě známých a sítě známých našich kolegů a kolegyň. Následně bylo využito kontaktování skrze hromadný e-mail studentkám našich kolegů a kolegyň a př́mé oslovení na doporučení spolužáků a spolužaček či vyučujících. Kromě velmi př́ísného kriteriálního výběru se ukázalo, že téma strachu žen je velmi citlivé až intimní téma vyžadující alespoň nějakou minimální míru důvěry. Domníváme se, že právě na základě důvěry lze interpretovat skutečnost, že jsme byli daleko úspěšnější v získávání komunikačních partnerek přes osobní sítě známých než přes kontaktování e-mailem či na doporučení někoho druhého. Díky tomuto postupu se nám v rámci jara roku 2016 podařilo úspěšně provést osm rozhovorů s ženami splňujícími všechna předdefinovaná kritéria. Pro výběr komunikačních partnerek přitom nebylo použito teoretické vzorkování a pro velikost vzorku pak ani princip teoretické saturace (Glaser a Strauss 1967: 61; Charmaz 2006: 96, 2008: 103), nicméně nižší počet komunikačních partnerek byl akceptovatelný kvůli velmi úzce nastavenému kriteriálnímu výběru na ženy s podobnou zkušeností (Smith a Osborn 2003; Smith, Flowers a Larkin 2009; Shinebourne 2011). Cílem takto konstruovaného vzorku pak nebylo reprezentovat celou tematickou šiři vztahu mezi dohledem druhých a vlastním strachem, ale popsat význam tohoto vztahu u velmi úzce nadefinované zkušenosti skupiny žen, a to s plným vědomím omezení, která z takto konstruovaného vzorku vyplývají pro zobecnění získaných zjištění.

Hlavní metodou výzkumu se staly polostrukturované rozhovory, které jsme zvolili z důvodu možnosti hlubšího proniknutí do studovaného tématu pocitu bezpečí, které může být, a často také bylo, poměrně osobní. Přítomnost pouze komunikační partnerky a tazatelky umožnila vytvořit poměrně intimní prostř̌edí a napomohla k osobnějším výpovědím. Zároveň polostrukturované rozhovory svou podstatou lépe umožňují reagovat na řečené, klást doplňující otázky a citlivěji reagovat na konkrétní zkušenost komunikačních partnerek. 
Polostrukturované rozhovory byly doplněny základními informacemi o komunikačních partnerkách (věk, obor studia, rodné město atp.). Základní informace o rozhovorech jsou uvedeny $\mathrm{v}$ tabulce 1 , přičemž všechny komunikační partnerky dále $\mathrm{v}$ textu vystupují pod pseudonymy. Rozhovory proběhly v Praze, Brně a Olomouci v dubnu a květnu 2016. Rozhovory v součtu trvaly 11 hodin a 7 minut, což v průměru znamená 1 hodinu a 23 minut na jeden rozhovor. Všechny rozhovory byly nahrávány, na což byly komunikační partnerky předem upozorněny, souhlasily s tím a podepsaly informovaný souhlas. Rozhovory byly doslovně přepsány a analyzovány pomocí softwaru ATLAS.ti. Analyzované přepisy všech rozhovorů čítají 506952 znaků včetně mezer, což představuje 281 normostran analyzovaného materiálu.

Tab. 1: Základní charakteristiky komunikačních partnerek

\begin{tabular}{|l|c|c|c|c|}
\hline Pseudonym & $\begin{array}{c}\text { Věk v době } \\
\text { rozhovoru }\end{array}$ & Datum rozhovoru & Místo rozhovoru & Délka rozhovoru \\
\hline Alžběta & 20 & 15.4 .2016 & Praha & $1: 24: 00$ \\
\hline Anna & 21 & 6.4 .2016 & Brno & $0: 48: 50$ \\
\hline Bára & 20 & 11.4 .2016 & Praha & $1: 20: 30$ \\
\hline Daniela & 20 & 12.4 .2016 & Praha & $1: 23: 56$ \\
\hline Klára & 21 & 24.5 .2016 & Brno & $1: 52: 41$ \\
\hline Markéta & 21 & 12.4 .2016 & Olomouc & $1: 29: 07$ \\
\hline Milada & 21 & 19.4 .2016 & Praha & $1: 26: 00$ \\
\hline Viktorie & 19 & 20.4 .2016 & Praha & $1: 22: 16$ \\
\hline
\end{tabular}

Jelikož data byla sbírána s obecnější výzkumnou otázkou, která se ptala po obavách spojených se samostatným pohybem $\mathrm{v}$ prostoru univerzitních měst, rozhovory pokrývaly širší paletu témat spojených se zvýznamňováním strachu z prostoru. Pro tento text byla nicméně zvolena nová, užší výzkumná otázka reflektující jedno z témat, které vyvstalo v průběhu rozhovorů. Jelikož se ptáme, jakým způsobem (prostorové i sociální) přenášení dohledu rodičů ovlivňuje strach jejich dcer z prostoru, předmětem analýzy je právě tento vztah. Jinými slovy prvotní čtení přepisů nás nejprve přivedlo $\mathrm{k}$ tématu zdrojů strachu, skrze které byl strach často zvýznamňován. Následně jsme si z těchto zdrojů vybrali ten, který z našeho pohledu produktivním způsobem problematizuje konceptuální oddělení mezi sobeckým strachem o sebe sama a zástupným strachem o druhé, tedy strach vlastních rodičů. A teprve poté jsme formulovali výzkumnou otázku pro tento konkrétní př́spěvek. Samotná analýza dat začínala $\mathrm{s}$ veškerým empirickým materiálem, nicméně pomocí kódování se postupně koncentrovala pouze na vlastnosti studovaného vztahu. Nejprve jsme tak kódovali všechny zmínky o matkách, otcích a obecně rodičích, ke kterým jsme následně ještě přidali zmínky o domově. Dále jsme kódovali výpovědi o předávaných obavách, pověstech a legendách. $V$ dalším kroku jsme se soustředili na průnik těchto dvou větších skupin, tedy na výroky spojené s předávanými obavami a rodiči. Ty jsme následně roztř́ídili dle nejrůznějších nástrojů kontroly komunikačních partnerek na telefon, SMS zprávu, e-mail, pepřový sprej, paralyzér, návraty domů, rady a doporučení. Na základě jejich vzájemného porovnání byly tyto nástroje následně rozděleny do tř́ skupin dle míry zprostředkování. Zatímco návraty domů, pepřový sprej 
a paralyzér byly zařazeny do skupiny nezprostředkovaných nástrojů, tak telefon, SMS, e-mail do částečně zprostředkovaných nástrojů a rady a doporučení do zprostředkovaných nástrojů dohledu. V poslední fázi pak byla vytvořena určitá časová posloupnost ve využívání těchto nástrojů při komunikaci mezi komunikačními partnerkami a jejich rodiči, kdy se ukázalo, že v čase postupně sílí podíl zprostředkovaných nástrojů kontroly nad těmi nezprostředkovanými. Empirická část tak popisuje tento mnohovrstevnatý vztah mezi strachem z prostoru komunikačních partnerek a způsoby přenášení dohledu jejich rodičů.

\section{Odchod z prímého dohledu}

Celé vyprávění tedy chronologicky začíná u odchodu z domova. Nejde nicméně o odchod definitivní, odchod do nového života, odchod ve smyslu opuštění, ale odchod ve smyslu odchodu z dohledu, mimo kontrolu, mimo dosah. Celá zkušenost přechodu z populačně malé obce na vysokou školu do populačně největších měst České republiky je spojována se vzdáleností, na kterou nebudou rodiče komunikačních partnerek již dále schopni dohlížet.

„To je velký a je to [...] Ty budeš od nás fakt strašně daleko. Tak když jedeš tak daleko a mezi tolik lidí, tak ti dáme ten pepřák, at' se ti nic nestane.“ (Klára, 21, 24. 5. 2016, zvýraznění autorů)

Komunikační partnerky v rozhovorech tematizovaly náročnost této změny, často hovořily, že pro ně tato změna byla spojena s různými poprvé - poprvé sama, poprvé v cizím městě, poprvé na nových místech, sama si nakupovat, sama si vařit, sama hospodařit atp. Nicméně současně dodávaly, že to bylo velmi náročné i pro jejich rodiče. Klára zde parafrázuje slova svých rodičů, kteří tematizovali především onu vzdálenost, míru onoho oddělení, které nejen, že bylo prostorově velké (vzdálené), ale univerzitní města pro ně byla vzdálená i jinak. Byla vzdálená nějak kvalitativně, byla odlišná, byla zkrátka jiná. Zatímco místa, kde žili se svými dcerami, byla malá, známá a bezpečná, univerzitní města byla naopak ta velká, cizí a nebezpečná. Zatímco zde se skoro všichni známe, je tady málo lidí, málo cizinců, nízká anonymita, tam nebudeš znát nikoho, všichni budou cizí, neznámí a kdovíjací. A co víc, nebudeme tam my, tví rodiče, nebudeme tam na tebe moci dohlížet, nebudeme ti moci poradit, nebudeme ti moci pomoci, kdyby bylo třeba. Místo toho nejen Klára dostala na cestu nějakou zbraň. Nejčastěji se jednalo o pepřový sprej či paralyzér. Komunikační partnerky tak ukazují, jak náročné bylo pro jejich rodiče nechat je odejít ze svého dohledu. Odchodem na vysokou školu se mezi komunikační partnerky a jejich rodiče vložila vzdálenost, jež problematizovala udržení rodičovského dohledu. Ten se tak transformoval do nabídky obranných prostředků, kterými se na jednu stranu snažil reagovat na neznámost ve vzdálené dálavě, ale kterou zároveň něco o této dálavě vypovídal, a to, že je nebezpečná, respektive že ji za nebezpečnou pokládají minimálně rodiče komunikačních partnerek.

„Je to vždycky i taková jako obět', kterou člověk musí přinést, jednak to stojí i dost peněz ty jízdenky, protože je to přes celou republiku skoro [...] takže člověk musí fakt něco podstoupit, aby se s těmi rodiči mohl shledat, takže je to pro mě hrozně vzácné $[\ldots]$ je vidět $[. .$.$] no ale mamince$ volám každý den, takže alespoň takhle.“ (Alžběta, 20, 15. 4. 2016, zvýraznění autorů) 
Alžběta pak nabízí i jiný rozměr oné vzdálenosti vložené mezi ji a její rodiče, která vedle prostých kilometrů stojí i čas, peníze a energii. Může se jednat i o cestu přes celou republiku, která představuje určitou obět', a nedá se tak např́ílad praktikovat př́liš často. Otázka délky odloučení je samožrejmě taktéž součástí této vzdálenosti. Komunikační partnerky odjížďjí nejčastěji na týden, obvykle na čtyři, či dokonce pět nocí, v neděli z domu a v pátek zpět. Nicméně i tato frekvence se $\mathrm{z}$ výše naznačených důvodů může prodlužovat a komunikační partnerky především ze vzdálenějších míst mohou postupovat v navyšování své vzdálenosti od rodičů, když se k nim začnou vracet např́klad pouze ve čtrnáctidenním či tř́ítýdenním opakování. Alžběta sama hovoří o tom, že to není tak často, jak by chtěla, že to je vlastně rídké, vzácné. Nicméně oproti tomuto principu dalšího vzdalování se uplatňuje i protichůdný princip jakéhosi zprostředkovaného přibližování, a to ve smyslu snižování jakési „informační vzdálenosti“, která je realizována skrze velmi častý telefonický kontakt. Komunikační partnerky vypovídaly o velmi častých, každodenních, a někdy dokonce i ještě častějšśch telefonických kontaktech realizovaných jak prostřednictvím samotného telefonátu, tak třeba SMS zprávou či e-mailem.

Tazatelka: A s ní voláte, třeba když jdete ve tři, ve čtyři ráno domů?

Bára: No, u nás je to takové [...] Můj otec je policista, takže on to paradoxně prožívá třeba ještě méně než moje máma, ale fakt jako hodně. Ona prostě, musím vždycky o sobě dát vědět, takže jó, klidně, ona neusne, dokud prostě nejsem doma [smích]. Takže myslím, že by jí to vủbec nevadilo [smích]. (Bára, 20, 11. 4. 2016, zvýraznění autorů)

Telefon se pro Báru stává jakýmsi prostředníkem mezi ní a rodiči, umožňuje jí zvýšit kontakt $v$ průběhu jejich odloučení, umožňuje snížit onu ,informační vzdálenost“" a současně umožňuje udržet jakýsi alespoň zprostředkovaný dohled rodičů. Nezř́́dka se tak v rozhovorech objevovaly výpovědi, popisující reportování rodičům o programu uplynulého a především následujícího dne, hlášení dojezdu na nějaké místo, hlášení posledního návratu domů atp. Komunikační partnerky ve svých výpovědích nezpochybňovaly tyto praktiky, hovořily o nich jako o něčem běžném, normálním, o zvyku „dát vědět domů“, že „už jsem doma“. Bára ve výše uvedené citaci používá sloveso „muset“, čímž minimálně naznačuje, že je to vyžadováno především ze strany rodičů, že ti to požadují, že to dokonce potřebují, že na to čekají a že by se v př́ípadě, kdyby se nedočkali, mohli obávat, strachovat, a to až tak, že by se napríklad nevyspali. Na druhou stranu na jiném místě Bára popisuje situace, ve kterých se necítí bezpečně, kdy dobrovolně volá mámě, aby „měla někoho na telefonu“, aby „nebyla tak úplně sama“, aby byla pod jejím alespoň zprostředkovaným dohledem. Telefon tak slouží jako obousměrné zprostředkování dohledu - moci dohlížet a současně být pod dohledem. Představuje tak určitou kontrolu chování, specificky zaměřenou na provozované aktivity, společnost, ve které jsou realizovány, místa těchto aktivit a časy těchto aktivit. Zcela největši míru zprostředkovaného dohledu pak komunikační partnerky popisují nad svým nočním chováním, které je poměrně př́sně kontrolováno posledním návratem domů - jakýmsi „večerním hlášením“. Zajímavým rozměrem přitom není ani tak ta skutečnost, že se přímý, ničím nezprostředkovaný dohled nad „tady“ transformuje do zprostředkovaného dohledu nad tím „tam“, ale že se dohled nad prostorem, se kterým rodiče komunikačních partnerek mají vlastní, každodenní a ničím nezprostředkovanou zkušenost, transformuje do dohledu nad 
prostorem, se kterým nemají nezprostředkovanou každodenní zkušenost, respektive se kterým mají výhradně pouze zprostředkovanou každodenní zkušenost. Tím se tento zprostředkovaný dohled „,na dálku“ stává něčím radikálně odlišným od nezprostředkovaného dohledu „nablízko“.

\section{Strach jako strategie dohledu „z dálky“}

Rodiče komunikačních partnerek, kteří $\mathrm{v}$ některém $\mathrm{z}$ univerzitních měst kdysi sami studovali, poprípadě kteří s nimi měli z nejrůznějších pracovních, rodinných či volnočasových důvodů alespoň nějakou zkušenost, nevystupovali ve vyjádřeních komunikačních partnerek tak ostražitě, jako rodiče, kteří tyto zkušenosti neměli. Obdobně tematizováni byli i prarodiče, jejichž reakce na odchod svých vnuček do velkých měst byla označována dokonce jako „zděšení“. Obecně byl tedy celý odchod rámován obavami z nového, vzdáleného a neznámého prostředí, které není pouze neznámé, ale je i nebezpečné, čekají v něm nejrůznější nástrahy, na které si je potřeba dát pozor, a především obavami z toho, že na tyto nástrahy budou komunikační partnerky samy, tedy bez dohledu svých rodičůu, poprípadě prarodičů. Vzdálenost a neznámost prostředí byla rodiči chápána jako komplikace dohledu hned ze dvou důvodů. Za prvé není možné na komunikační partnerky dále dohlížet, protože budou daleko, za druhé na ně není možné dohlížet, protože prostředí, do kterého odcházejí, je pro jejich rodiče neznámé. Jinými slovy je tě̌̌ké provádět dohled, když nevíte, na co je třeba dohlížet. Komunikační partnerky v tomto kontextu tematizovaly přenášení strachu rodičů na ně. Rodiče jim vyprávěli nejrůznější historky, upozorňovali na nejrůznější kauzy, vymýšleli katastrofické scénáře atp.

„My jsme to takhle řešili dva roky nazpátek, jela jsem na brigádu do Anglie. A to bylo hodně velký, to já jsem měla, každý den mi táta dával proslovy o tom, co se může stát, a ted'ka ještě četl článek, že se rozšíriila ebola, tak říkal: Ty tam beztak něco chytíš, ebola nebo malárie. Ǩíkám: Tati, tam malárie není. A on: Ale ty to chytíš. Nebo: Londýn je velký město, tam nemůžěs, tam se ti něco stane a ted'ka nějací ti imigranti. A ř́kám: Ale tati, já ani nebudu v Londýně, já budu v nějaké vesnici na jihu, co by se mi mohlo stát. A ty nevíš, nebo poletišs letadlem a to letadlo spadne a všechny možný situace, který by se mi mohly stát, tak on to shrnul. Každý den vymýšslel novou katastrofu. Každý den př̌išel s něčím novým, co by se mi mohlo stát." (Klára, 21, 24. 5. 2016, zvýraznění autorů)

Klára zde popisuje situaci ještě před jejím nástupem na vysokou školu, kdy letěla na jedno léto pracovat do Anglie. Její otec na její tehdejší první delší odchod z dohledu reagoval podle jejích vlastních slov „,přehnaně“, když jí každý den dával proslovy a vymýšlel katastrofické scénáře o tom, co všechno se jí může stát. Klára zde př́mo nehovoří o tom, jaký to na ni mělo vliv. V dikci výpovědi lze identifikovat určitý odstup či nadhled nad celou situací, jako by se jí to nedotýkalo, jako by to na ni nemělo žádný vliv, jako by se již jednalo jen o zábavnou historku z dětství. Její výpověd’ nicméně velmi hezky vyjadřuje reakci otce na její první odchod. Způsob, jakým se vyrovnával s tím, že jeho dcera, která do té doby žila pod kontrolou jejich společného bydlení, odejde někam mimo tento dohled, někam, kam on jen obtížně může dohlédnout, dosáhnout, zasáhnout. Výpověd' ukazuje, jaké všechny strachy z neznámého se u něj objevily - strach z cesty, strach z dopravní nehody, strach z onemocnění, 
strach z přepadení, snad i strach ze znásilnění. Jako by ji nechtěl pustit, jako by ji chtěl držet doma, pod dohledem, ve svém dosahu, v jakémsi hypotetickém „bezpečíc“ Nicméně Klára následně do Anglie i s jeho svolením odjela. Jeho výpovědi o straších, jeho děšení a předávání svých strachů tak ukazují spíše na jakousi strategii přípravy spočívající v tom, že když ji otec nemůže mít pod dohledem, tak by alespoň měla vědět o všech možných nebezpečích, se kterými se Klára není zvyklá setkávat, ale tam se s nimi setkat může. V tomto kontextu je zajímavá i tematizace onoho „tam“, u kterého otec nerozlišuje nějakou vesnici na jihu Anglie a Londýn, obojí je pro něj někde v daleké cizí zemi, a tak mají více společného než odlišného (obě jsou vzdálené a cizí). Přesto, že celý tento příklad není o univerzitních městech v České republice, je o prvním delším odchodu od rodičů, který v jakési hypertrofované podobě odkrývá, co se opakuje i při odchodu na vysokou školu.

„To bere hodně, on, když kouká na televizi a většinou na zprávy, tak spousta věcí se děje v Praze. Jako že třeba [...] anebo i ve velkých městech cokoliv se děje, i ted' třeba, v téhle situaci, kdy jsou někde ty teroristický útoky, má jako strach, má strach z toho, že tady je metro a že se může něco stát, má strach $\mathrm{z}$ toho, že se tady v noci potuluje spousta lidí, má strach z bezdomovců, protože to nezná, protože u nás to není. A když tady byl se podívat, jeden den, a byl hrozně překvapenej z toho, kolik lidí tady prostě je na ulici. A byl z toho hrozně vyděšenej. A právě že jakoby spíš toho se bojí, že se prostě stane něco hrozně snadno a už mě nikdo nenajde třeba." (Daniela, 20, 12. 4. 2016, zvýraznění autorů)

Výpověd' Daniely tak ukazuje, jak podobné si mohou být výpovědi o odchodu do daleké ciziny a do velkého univerzitního města. Ebolu, malárii či letadlo zde nahrazuje metro, cizinci či bezdomovci. Přitom nejde o právě tyto konkrétní entity, jde o jejich odlišnost, cizotu, neznámost, zkrátka něco, s čím nemají rodiče komunikačních partnerek přímou, nezprostředkovanou zkušenost. Daniela zde popisuje i odkud její rodiče berou informace o neznámém prostředí, ve kterém ona žije. Hlavním zdrojem jsou pro ně různé druhy médií, jako televize, zprávy v televizi, zprávy v novinách, rádiích či na internetu. Rodiče tak nejen že nemají nad svými dcerami dohled, ale ani nemají př́mou, nezprostředkovanou zkušenost s jejich prostředím. Výše uvedená výpověd' Daniely nicméně ukazuje, že i když rodiče pozve, oni přijedou a mohou zažít na svou vlastní kůži místa, kde jejich dcera žije, kde studuje, kam chodí a kde se pohybuje, tak toto jednorázové nezprostředkované seznámení nemusí nutně vést $\mathrm{k}$ obeznámenosti $\mathrm{s}$ těmito místy a ke snížení obav z jejich nebezpečnosti. Dokonce to může vést k naprostému opaku, tedy k potvrzení, či dokonce zvýšení obav z tohoto prostředí. Komunikační partnerky v těchto prostředích žijí, dlouhodobě zde praktikují své každodenní rutiny, jejich zkušenost se zakládá na opakovaných, ničím nezprostředkovaných setkáních s tímto prostředím, které tak zakládají určitou elementární obeznámenost s tím, co je v těchto prostředích možné, co je normální, jak se chovají atp. Oproti tomu jednorázová návštěva tuto obeznámenost nezakládá, není spojená s každodenním opakováním, není založená na vlastní zkušenosti s bezpečným pobytem v těchto prostředích a zdůrazňuje spíše odlišnost navštívených prostředí od těch, s nimiž jsou rodiče komunikačních partnerek dobře obeznámeni a kde oni opakují své každodenní rutiny. Komunikační partnerky tak nehodnotily jednorázové představení svých nových prostředí rodičům jako př́liš úspěšnou strategii ve snižování jejich obav o ně. 
„Asi mamka, mamka do mě asi hučela často, at’ se vyhnu nějakým nebezpečným místům, že abych tam nechodila.“(Markéta, 21, 12. 4. 2016, zvýraznění autorů)

Na základě obeznámenosti rodičů s novými prostředími svých dcer pak komunikační partnerky byly varovány bud' obecně před nebezpečným prostředím celého města, nebo pouze před určitými vybranými místy. Komunikační partnerky hovořily o různých zdrojích informací svých rodičů, kteří nejčastěji vycházeli z jakési „vlastní“ zkušenosti, jež nicméně zdůrazňovala běžně opakované stereotypy jako hlavní nádraží, parky, opuštěná místa, tmavá místa atp. Často byly nicméně mezi zdroji informací rodičů o nebezpečnosti nových prostředích zmiňovány „vlastni“ zkušenosti blízkých, známých či přátel, nejrůznější média, či dokonce vlastní pátrání. V několika př́padech komunikační partnerky vypověděly, že jejich matky prováděly určitý druh výzkumu na internetu, kde pátraly po nejrůznějších informacích, kde a kdy se $\mathrm{v}$ nových prostředích jejich dcer udála nějaká nehoda, incident, či dokonce zločin. Tyto informace pak s komunikačními partnerkami sdílely s důrazným doporučením, aby se těmto místům vyhýbaly. Komunikační partnerky tak před samotným odchodem do cizího prostředí byly důrazně poučeny o nebezpečnosti vzdáleného prostředí. Tato poučení měla většinou dvě odlišné podoby. V podstatě všichni rodiče komunikačních partnerek zdůrazňovali nebezpečnost celého prostředí města a nabádali k bezpečnému chování, které zahrnovalo nechodit sama, nechodit na neznámá místa, nechodit v noci, nepít alkohol atp. Pouze v některých př́padech komunikační partnerky, jako např́klad Markéta, uváděly, že je rodiče vybavili i seznamy konkrétních míst, poprípadě městských částí, kterým by se měly v novém prostředí vyhnout.

\section{Bez strachu není ani dohledu „z dálky“}

Transformace prímého, nezprostředkovaného dohledu na zprostředkovaný dohled z dálky se realizovala několika způsoby, které byly všechny spojeny s vyvoláváním pocitu ohrožení, zvyšováním obezřetnosti, předáváním strachu. Nejčastěji byla používána kombinace zdůrazňování vyšší míry nebezpečnosti nového prostředí, nabádání k bezpečným způsobům chování, telefonická kontrola jejich dodržování, vybavení ochrannými prostředky (pepřový sprej, paralyzér) atp. Nicméně všechny tyto nástroje zprostředkovaného dohledu $\mathrm{z}$ dálky měly společný jmenovatel, a to sdělení, že komunikační partnerky jsou v permanentním ohrožení, v permanentním nebezpečí, a je nutné, aby byly stále obezřetné. Tento dohled nicméně stavěl komunikační partnerky do poměrně komplikované situace, ve které kdyby neměly dle svých rodičů $\mathrm{v}$ neznámém městě plném neznámých lidí chodit samy na neznámá místa, tak by podle vlastních slov „musely jen sedět na koleji, nikam nechodit a s nikým se neseznamovat“. Samotná nutnost chodit do školy, chodit do knihovny, chodit na tělocvik, chodit nakupovat, chodit na nádraží a pohybovat se v cizím prostředí mezi těmito místy je nutila vybrat si porušení minimálně jednoho z pravidel, bud' nechodit sama, nebo nechodit $\mathrm{s}$ nikým neznámým. Jinými slovy komunikačním partnerkám nezbylo nic jiného než tato pravidla svých rodičů nebrat zcela doslovně a jejich obavy z neznámého prostředí systematicky překonávat. 
„Je mi více sympatické, protože mi najednou přijde více domácí, už pro mě není tak chladné, cizí, jak to bývalo na začátku, že už vím, třeba mám přehled $v$ metru, $v$ některých tramvajích a tak dále, což mi dodává jistý pocit bezpečí, dá se říct.“(Alžběta, 20, 15. 4. 2016, zvýraznění autorů)

Alžběta zde hovoří o své opakované zkušenosti s prostředím. Tímto opakováním, tímto téměř nepostřehnutelným rutinním zakoušením se mění celá řada věcí, které je nicméně možné jen obtížně zprostředkovat. Za prvé, původně neznámé prostředí nového města přestává být pro Alžbětu až tolik neznámé, již nechodí pouze na nová místa, už opakuje své cesty po místech, kde již předtím byla, která zná, o kterých ví a o kterých tak má přehled. Přestává se tedy sama pohybovat po neznámých místech, ale začíná se sama pohybovat po známých místech. Získává tedy samostatnost pohybu, respektive samostatnost pohybu po těchto známých místech pro ni přestává být nadále nebezpečná. Za druhé, ztrácí strach ze ztracení se, ze zabloudění, začíná se orientovat v novém prostředí, což znamená, že získává kontrolu nad svým pohybem ve veřejném prostoru. Začíná přebírat dohled sama nad sebou. Za třetí, díky mnoha opakovaným návštěvám těchto míst, v rámci kterých se jí v nich nestalo nic nebezpečného, kdy nebyla vystavena žádnému riziku, kdy jí nic nehrozilo, Alžběta ztrácí svou původní ostražitost a tato původně neznámá místa se pro ni začínají stávat známými, normálními, bezpečnými. A za čtvrté, pohybem po těchto rutinních místech získává i obecnější představu o podobě ostatních míst v prostředí neznámého města, o způsobech chování v nich, o situacích, se kterými se v nich může setkat, a skrze obeznámenost s těmito prvními místy se seznamuje i s jinými místy v neznámém prostředí nového města, na které se tak díky nim může snáz připravit a kterých už se nemá důvod tolik obávat. O této základní obeznámenosti s těmito prvními místy poté Alžběta hovoří dokonce jako o jakési jistotě, která jí dodává pocit bezpečí a která ustavuje jejich novou domáckost.

„Jo, sem tam mi zavolá a třeba jednou mi volal asi v osm hodin a zrovna jsem seděla $\mathrm{v}$ tramvaji a v té chvíli byl překvapenej, že někam ještě jedu. Jsem zrovna odjížděla z koleje, a tak mě upozorňoval, at' si dám hlavně pozor, když jedu takhle navečer.“ (Daniela, 20, 12. 4. 2016, zvýraznění autorů)

Nicméně tato změna $\mathrm{v}$ obeznámenosti s neznámým prostředím nového města je praktikována pouze u komunikačních partnerek, nikoliv u jejich rodičů. Zatímco pro komunikační partnerky se prostor postupně transformuje z neznámého na méně neznámý až na známý, pro jejich rodiče zůstává nový prostor jejich dcer zpravidla stále stejně neznámým. Postupně tak dochází k určitému oddělení původně blízkých náhledů na toto „neznámé“ prostředí, kdy komunikační partnerky přestávají dbát rad svých rodičů a ve svém známějším prostředí si dovolují více, než si dovolily v neznámém prostředí dříve. Jedním z projevů tohoto oddělení je, že komunikační partnerky ve svých výpovědích přiznávají, že se přestávají svým rodičům svěřovat se vším, přestávají jim podávat tak přesné informace o tom, kde, kdy a s kým byly či plánují být, jako to činily dříve. Ve výpovědích se objevovala i vyjádření, že pokud by se jim snad něco přihodilo, že by to raději rodičům ani neřekly: ,k ničemu by to nebylo, akorát by je to vystrašilo". Tak, jak se komunikační partnerky postupně seznamují s novým prostředím, ztrácejí z něj obavy, začínají se dostávat do určitého nesouladu se svými rodiči, kteří tyto obavy stále mají. Z důvodu obtížné zprostředkovatelnosti jejich opakované, 
nezprostředkované zkušenosti s „bezpečností“ nových míst neznámého prostředí a obtížně realizovatelného umenšení obav svých rodičů, se komunikační partnerky postupně uchylují ke strategii omezování sdělovaných informací o svém prostorovém chování. Výše uvedená citace Daniely nicméně dokládá, že rodiče se o tomto chování dozvídají alespoň zprostř̌edkovaně. Výrok Daniely nicméně také ukazuje na omezenou vymahatelnost dodržování rodičovských rad. Pokud komunikační partnerky nedbají rad svých rodičů, může z jejich strany přijít překvapení, upozornění či doporučení, kterými shodně vyjadřují svůj nesouhlas s novým chováním komunikačních partnerek, nicméně žádná z komunikačních partnerek v tomto kontextu netematizovala žádné zákazy, př́kazy či direktivní nařízení.

„Ale takový dávej si pozor. Velký město. Velký nebezpečí. Musíš mi dát vědět. Musím se hlásit doma furt, co dva dny, protože jakmile se neozvu včas, tak už jenom varovná esemeska, nemám zprávy o své dceři, a tak.“

(Viktorie, 19, 20. 4. 2016, zvýraznění autorů)

Postupně je tak oslabován i onen zprostředkovaný dohled rodičů komunikačních partnerek z dálky. Nejen, že nedochází ke sdílení takového množství informací v takovém detailu jako v prvotních fázích pobytu mimo přímý dohled rodičů, ale současně slábne i samotný kontakt, a to nejen prímý, nezprostředkovaný, fyzický, ale i ten neprímý, telefonický, zprostředkovaný. Viktorie ve výše uvedené citaci připouští situace, kdy se neozve v čas, který byl smluvený, který byl používaný, který byl dodržovaný. Telefonická kontrola prostřednictvím SMS zprávy v jejím př́ípadě běžně probíhala jednou za dva dny, nicméně postupně je nutné její opakování připomínat. Dožadování neustálého praktikování alespoň těchto zprostředkovaných forem dohledu od rodičů odkrývá oslabování potřeby tohoto dohledu od Viktorie. Zatímco komunikační partnerky prožívají jedno z nejdynamičtějších období, kdy se vedle nové školy, nového města, nových míst a nového bydliště seznamují i s velkým množstvím nových lidí, jejich rodiče zpravidla setrvávají ve známém prostředí mezi svými známými. Proces vytváření obeznámenosti komunikačních partnerek s novými místy a s novými lidmi, kteří nejsou nově těmi vzdálenými, ale naopak těmi blízkými, je pro jejich rodiče jen obtížně uchopitelný. Dochází tak paradoxně k postupné proměně toho, kdo je pro koho blízký, respektive od čeho je tato blízkost odvozována. Zatímco komunikační partnerky zůstávají pro své rodiče (žijící ve svém „původním“ světě obeznámenosti) nadále blízké, a to i přes to, že žijí daleko a oni nad nimi nemají př́mý dohled, rodiče pro komunikační partnerky (žijící v „novém“, velmi dynamicky se vyvíjejícím světě) naopak přestávají být tak blízcí, protože jsou daleko a nemají nezprostředkovaný př́stup k tomu všemu „novému“.

\section{Internalizace dohledu}

To nicméně samo o sobě neznamená, že by komunikační partnerky nadále neměly žádné obavy, že by se přestaly bát samy $\mathrm{v}$ noci venku, že by se zcela zřekly rad svých rodičů. Z výpovědí vyplývá, že zatímco rodiče přestali kontrolovat jejich prostorové chování, jejich dohled s nimi zůstal i nadále. Dokonce lze ve výpovědích nalézt i přímou kontrolu, prímý, ničím nezprostředkovaný dohled, který pouze již nepatří rodičům komunikačních 
partnerek. Nicméně i tento nezprostředkovaný dohled lze na dálku zprostředkovaně kontrolovat. Nejčastěji se jedná o spolubydlící, spolužáky či partnery, u kterých rodiče očekávají, že alespoň částečně převezmou jejich roli, tedy roli dohlížejících.

„To ne, ale mě se naši ptají: A př̌ǐel ti tam naproti?““(Klára, 21, 24. 5. 2016, zvýraznění autorů)

Nalezení nových prátel mezi spolužáky, spolubydlícími, a především pak nalezení partnera jsou klíčové momenty vytvoření nových vazeb nejen $\mathrm{k}$ lidem, ale i $\mathrm{k}$ místům a přeneseně pak i k celému městu. Je to něco jako vytvoření si jakési nové, „náhradní“ rodiny, tedy náhradní v tom smyslu, že do jisté míry přebírá určité role „původní“ rodiny, respektive role vzdálených rodičů. $\mathrm{V}$ určitém smyslu se nemusí jednat pouze o metaforu, ale skutečně o novou rodinu, tedy rodinu partnera. Alžběta níže hovoří o tom, že se v novém, neznámém městě, vzdálena od vlastní rodiny, cítila sama. Jako by o vlastní rodinu tou vzdáleností nějakým způsobem přišla, jako by se z ní pouze tímto přemístěním do nového města stal sirotek. Nalezení partnera a seznámení se s jeho rodinou tak neznamená vstup do nové rodiny de iure, ale pro Alžbětu de facto. Alžběta na jiném místě popisuje, jak jí partnerova rodina pomohla s vyhledáním lékařských specialistů, když byla vážně nemocná, bylo jí velice špatně a vůbec nevěděla, jak se má sama o sebe postarat. Popisuje, jak se jí rodina partnera ujala, jak jí pomohla nalézt různé kontakty, jak jí vytvořila pocit zázemí a jistoty.

„Určitě je to už lepší a hodně mi pomohlo, že jsem si tady našla právě prítele. Ten mi vždycky poradí nebo mě třeba i zaveze někam. Poradí, kde co najít nebo [...] prostě člověk má tady takové jakoby zázemí. I jeho rodiče se ke mně postavili trošku jako k sirotkovi (s úsměvem), takže mi taky jakoby v mnohém pomáhají a tak, že cítím, že tady jakoby mám nějaké to zázemí, nějakou rodinu de facto $[\ldots]$ že jsem je tak docela i začala brát [...] že určitě je to lepší, nepřijdu si tady sama." (Alžběta, 20, 15. 4. 2016, zvýraznění autorů)

Nová rodina tak do jisté míry přebírá roli té původní, a to včetně dohledu. Nová rodina nicméně nekontroluje chování komunikační partnerky přímo, ale opět zprostředkovaně, skrze kontrolu chování svého vlastního syna, který doprovází novou dceru/snachu a zabezpečuje její dohled. Alžběta nicméně přiznává, že jí tento př́stup není nikterak nepř́ijemný, ba naopak, je na něj zvyklá, a co víc, tento dohled přímo vyžaduje. Její partner ji podle jejích vlastních slov (níže) dř́ve nechával jít samotnou, dokázal ji nechat jít samotnou dokonce i v noci - pustit ji samotnou, opustit ji. Nicméně to sama nepokládá za vhodné chování partnera a vyžaduje jeho dohled. Dokonce sama vyjadřuje prrání, aby ji „nepouštěl“ samotnou. Dohled tedy není jen nabízen, ale i požadován. Nenechat jít ženu samotnou, doprovodit ženu, popř́ípadě jí alespoň zajistit doprovod patř́ $\mathrm{k}$ představě správně vychovaného gentlemana jak v představě samotné Alžběty, tak jejích rodičů, i rodičů jejího partnera. Nemuset jít sama, nemuset se pohybovat po městě samostatně představuje nejen Alžbětou preferovanou variantu pohybu po novém městě. Tato preference je samozřejmě zesílena v př́padě tmavé části dne a v prrípadě neznámých míst, nicméně lze ji identifikovat i v odlišných kontextech, jako napríklad na různých akcích, demonstracích, průvodech, festivalech či jakýchkoliv větších koncentrací lidí, v kontextech pikniků, pobytu v parcích, učení se ve veřejném 
prostoru, či v kontextech vzdálených, komplikovaných či jakkoliv organizačně nesnadných cest. Samostatný pobyt ve veřejném prostoru tak komunikační partnerky neproblematizují $\mathrm{v}$ podstatě jenom $\mathrm{v}$ kontextu pohybu po relativně dobře známých, zrutinizovaných cestách ve světlé části dne. Ve všech ostatních kontextech pobytu ve veřejném prostoru komunikační partnerky preferují doprovod.

\begin{abstract}
„No tak asi obecně všechny místa, kde bych měla jít sama třeba večer to [...] př́itel má přísně zakázáno i od rodičůu, aby mě někde pouštěl samotnou, takže protože občas se stávalo, a to mi dost vadilo na něm že $[. .$.$] i když to mám od něj na kolej asi patnáct minut pěšky, takže mě někdy$ nechal prostě jít samotnou i [důraz] v noci třeba, a to mi hodně vadilo, protože jsem si ř́kala, ono je jedno, že to je Břevnov, jako dobrá část, ale někdo prostě, nějaký násilník může být i tam že jo [...] ale naštěstí už se teda jako naučil mě fakt nepouštět, takže i když je to kousíček, tak mě bud' vždycky [důraz] zaveze, protože má auto, anebo už se stalo, že mi objednal i taxíka, prostě abych nemusela jít samotná, tak to se mi docela líbí.“ (Alžběta, 20, 15. 4. 2016, zvýraznění autorů)
\end{abstract}

Komunikační partnerky tak i bez zprostředkovaného dohledu vlastních vzdálených rodičů dodržují určitá pravidla „bezpečného“ chování v prostředí „,nového“ města. Přestože se žádné z komunikačních partnerek podle jejich vlastních slov ve veřejném prostoru „nových“, univerzitních měst nikdy nic nestalo, udržují v sobě tuto ostražitost, a pokud to není vyloženě nutné, neporušují tato původní, dnes již nikým nekontrolovaná, a tak vlastně neviditelná pravidla vlastního prostorového chování. Komunikační partnerky se tak do jisté míry omezují jen na určitý, poměrně úzký prostor rutinních cest, ve kterém se pohybují samy, a to ještě pouze ve světlem vymezené části dne. Pokud to není nezbytně nutné, nová místa, nové trasy, popř́ípadě noční časy rozšiřují tento zrutinizovaný prostor výhradně ve společnosti někoho druhého. Pro realizaci jakýchkoliv aktivit vykonávaných ve veřejném prostoru vyjma prostého pohybu (chůze, běh) je pak i v rámci tohoto zrutinizovaného prostoru opět preferována společnost někoho známého. I přesto, že prostorové chování komunikačních partnerek přestává být nadále rodiči kontrolováno, tyto neviditelné principy prostorového chování jsou i nadále dodržovány. Komunikační partnerky je internalizují a i nadále udržují samy sebe v jakýchsi neviditelných bariérách strachu z „nového“ města.

„Vybíráme jakoby právě, protože právě se mi líbí, že Praha je místo úplně hrozně moc možností, a byla by škoda chodit jenom na jedno místo. To jako já ráda poznávám nový věci, ale jako zase ne sama. Takhle si ř́ct, tady jsem ještě nebyla, tak se tam jdu podívat $[\ldots]$ ale spíš jdu okolo, řeknu si, tady to vypadá dobře, tak zkusím příšstě navrhnout, že bychom šli sem.“" (Daniela, 20, 12. 4. 2016, zvýraznění autorů)

\title{
Závěr
}

Předložený př́spěvek popsal mnohovrstevnatý vztah mezi strachem a dohledem, a to ve velmi specifické zkušenosti osmi studentek vysokých škol v prvním a druhém ročníku studia pocházejících z populačně malých obcí. Postupně tak bylo ukázáno, jak si ztráta přímého dohledu rodičů nad komunikačními partnerkami vyžádá novou strategii zprostředkovaného dohledu rodičů, která využívá strach jako nástroj pro disciplinaci prostorového chování komunikačních partnerek. Následně, jak se komunikační partnerky seznamují s prostředím 
univerzitních měst, se i tato strategie zprostředkovaného dohledu rodičů vyčerpává. Nicméně komunikační partnerky nadále opakují vzorce prostorového chování, a to i přes absenci jeho kontroly. Po ztrátě zprostředkovaného dohledu rodičů tak komunikační partnerky přebírají dohled samy nad sebou, respektive samy vyžadují tento dohled nad sebou od druhých.

Strach o sebe a strach o druhé tedy nemusejí být nutně dva oddělené koncepty. Jak ukazuje zkušenost našich komunikačních partnerek, mohou být vzájemně provázané. Strach rodičů o komunikační partnerky může vstupovat do strachu komunikačních partnerek o sebe samé, a naopak strach komunikačních partnerek o sebe samé může vstupovat do strachu jejich rodičů o ně. Ze zkušeností našich komunikačních partnerek je zřejmé, že se jejich rodiče musí vyrovnávat s tím, že nejsou schopni realizovat přímý dohled nad svými dcerami. Mění se tak forma jejich dohledu, který se stává neviditelným, zprostředkovaným. Využivají jiných prostředků, aby se ujistili, že jsou jejich dcery v bezpečí, či zajistili, aby tomu tak bylo. Typickým prostředkem, který reprezentuje neviditelný dohled rodičů, je telefon, jehož prostřednictvím kontrolují komunikační partnerky, ujišt'ují se, že je vše v pořádku (varovná SMS), ale i zjišt'ují, kde a s kým se právě nacházejí, co dělají atp. Zároveň je ale telefon využíván i opačným způsobem, když se komunikační partnerky necítí zcela bezpečně, tak samy telefonují svým rodičům, aby byly pod určitým, technologicky zprostředkovaným dohledem. Původně od rodičů vyžadované „,měj u sebe telefon, kdyby něco..." se tak proměňuje na jednu ze strategií zvládání vlastního strachu (více Osman a Jíchová 2019).

Používání telefonu ale není jediným př́kladem, jak se dohled rodičů podílí na prožívaném strachu komunikačních partnerek. Komunikační partnerky se postupně s prodlužujícím pobytem na původně novém, neznámém místě svého strachu zbavují, nedodržují plně rodičovské pokyny a rady, redukují informace, které jim předávají, aby je př́liš neděsily, u některých se postupně snižuje četnost návštěv doma atp. I přesto je zřejmé, že naučená a dř́ve provozovaná opatření, nechodit sama, nechodit sama v noci, nechodit sama v noci na neznámá místa, dávat si pozor na určité lidi, přetrvávají a komunikační partnerky se jimi ř́dí i nadále. Tato zjištění potvrzují i výsledky výzkumů zaměřených na roli rodičů, na utváření strachu dětí z míst, osob apod. (May et al. 2002; De Groof 2008), včetně vnímání rizikovosti pohybu venku, zejména po setmění, samy a/či v místech s „rizikovou“ nálepkou (Foster et al. 2014). Zároveň ale výsledky naznačují, že určitá schémata chování, reakcí a strategií v kontextu strachu z pohybu městem si vytvářejí komunikační partnerky i v dospělém věku. Ukazuje se, že prostředí „,nových“ měst pro ně zatím stále nepřestávají být „novými“, že své prostorové chování v nich podřizují jakýmsi neviditelným bariérám, tedy že i nadále vyžadují dohled nad většinou svého pobytu ve veřejném prostoru.

Prostřednictvím popisu vztahu mezi strachem a dohledem tak př́íspěvek představil způsoby, jak dohled nad druhými ovlivňuje strach těchto druhých a zároveň i jak strach těchto druhých ovlivňuje dohled prvních. Ve zkušenosti vysokoškolských studentek pocházejících z populačně menších obcí se ukazuje, že jde o oboustranný vztah, který se navíc v čase vyvíjí. Jak dohled, tak i strach nabývá v procesu seznamování se komunikačních partnerek $\mathrm{s}$ univerzitními městy odlišných významů. Zatímco na počátku tohoto procesu je dohled spíše zdrojem jejich strachu, posléze se strach emancipuje od dohledu, tak v konečné fázi se strach naopak stává zdrojem jejich dohledu. $Z$ důvodu, že by snaha o odlišení různých zdrojů strachu pravděpodobně nebyla prríliš produktivní, a jelikož se předložený př́spěvek věnoval 
pouze jednomu vybranému zdroji strachu - dohledu rodičů, nelze na základě dostupných dat přesvědčivě doložit, že prezentované pocity strachu komunikačních partnerek vyvěrají pouze z dohledu jejich rodičů, a nikoliv i z jiných zdrojů. Lze však přesvědčivě doložit, že se prožívaný strach ve výpovědích komunikačních partnerek pojí s dohledem nad nimi a jakých podob toto spojení nabývá. Bylo by přitom nevhodné vnímat strach komunikačních partnerek jako jejich dominantní emoci z příchodu do univerzitních měst. Zaměření na téma strachu není volbou komunikačních partnerek, které by si jej samy zvolily jako základní způsob uchopování své zkušenosti s příchodem do univerzitních měst. Téma strachu bylo apriorní volbou výzkumnic a výzkumníka, kteří se na něj zaměřovali jak při sběru, tak i analýze dat. Zkušenost komunikačních partnerek s příchodem do „nového“ města je zajisté daleko bohatší a nelze ji redukovat pouze na zkušenost strachu z „,nového“ prostoru, která se stala předmětem tohoto konkrétního př́spěvku.

\section{Literatura}

CRAWFORD, Sharinne B. et al. 2017. „Worries, ,Weirdos‘, Neighborhoods and Knowing People: A Qualitative Study with Children and Parents Regarding Children's Independent Mobility." Health \& Place 45: 131-139.

DE GROOF, Saskia. 2008. „And My Mama Said... The (Relative) Parental Influence on Fear of Crime among Adolescent Girls and Boys.“ Youth \& Society 39(3): 267-293.

DRAKULICH, Kevin M. 2014. „Concerns for Self or Family? Sources of and Responses to Altruistic Fear." Journal of Interpersonal Violence 30(7): 1168-1207.

FERRARO, Kenneth F. 1995. Fear of Crime: Interpreting Victimization Risk. Albany, NY: SUNY Press.

FOSTER, Sarah, Karen VILLANUEVA, Lisa WOOD, Hayley CHRISTIAN a Billie GILLES-CORTI. 2014. „The Impact of Parents' Fear of Strangers and Perceptions of Informal Social Control on Children's Independent Mobility.“ Health \& Place 26: 60-68.

GLASER, Barney a Anselm STRAUSS. 1967. The Discovery of Grounded Theory: Strategies for Qualitative Research. Chicago: Aldine Publishing Company.

GLASSNER, Barry. 2009. The Culture of Fear: Why Americans are Afraid of the Wrong Things: Crime, Drugs, Minorities, Teen Moms, Killer Kids, Muta. $2^{\text {nd }}$ edition. New York: Basic Books.

GRUSZCZYNSKA, Beata a Marek GRUSZCZYNSKI. 2005. „Crime in Enlarged Europe: Comparision of Crime Rates and Victimization Risks.“ Transition Studies Review 12(3): 337-345.

HALE, Chris. 1996. „Fear of Crime: A Review of the Literature.“ International Review of Victimology 4(2): 79-150.

HEBER, Anita. 2009. „,The Worst that Could Happen“: On Altruistic Fear of Crime.“ International Review of Victimology 16(3): 257-275.

CHARMAZ, Kathy. 2006. Constructing Grounded Theory: A Practical Guide through Qualitative Analysis. London: SAGE Publications.

CHARMAZ, Kathy. 2008. „Grounded Theory.“ Pp. 81-110 in Jonathan A. SMITH (ed.). Qualitative Psychology: A Practical Guide to Research Methods. Los Angeles: SAGE Publications.

MADRIZ, Esther. 1997. Nothing Bad Happens to Good Girls: Fear of Crime in Women's Lives. Berkeley: University of California Press.

MAY, David C., Lesa R. VARTANIAN a Keri VIRGO. 2002. „The Impact of Parental Attachment and Supervision on Fear of Crime among Adolescent Males.“ Adolescence 37(146): 267-287. 
Robert Osman, Jana Jíchová: „A prǐšel ti naprotię“: dohled rodičů jako neviditelná bariéra...

OSMAN, Robert a Jana JÍCHOVÁ. 2019. „Pohyb pod dohledem / Geografie ,prvaček“ “ Pp. 111-145 in Robert OSMAN a Lucie POSPÍŠILOVÁ (eds.). Geografie „okrajem “: každodenní časoprostorové zkušenosti. Praha: Karolinum.

PAIN, Rachel. 1997. „Social Geographies of Women's Fear of Crime.“ Transactions of the Institute of British Geographers 22(2): 231-244.

PODANÁ, Zuzana a Eva KRULICHOVÁ. 2018. „The Impact of Parenting Style on Fear of Crime among AdolescentGirlsandBoys.“JournalofYouthStudies[online].DOI:10.1080/13676261.2018.1449945.

SHINEBOURNE, Pnina 2011. „The Theoretical Underpinnings of Interpretative Phenomenological Analysis." Existentical Analysis 22(1): 16-31.

SIEBEL, Walter a Jan WEHRHEIM. 2006. „Security and Urban Public Sphere.“ German Policy Studies 3(1): 19-46.

SMITH, Jonathan, A., Paul FLOWERS a Michael LARKIN. 2009. Interpretative Phenomenological Analysis: Theory, Method and Research. London: Sage Publications.

SMITH, Jonathan, A. a Mike OSBORN. 2003. „Interpretative Phenomenological Analysis.“ Pp. 53-80 in Jonathan A. SMITH (ed.). Qualitative Psychology: A Practical Guide to Research Methods. London: Sage Publications.

SNEDKER, Karen A. 2006. „Altruistic and Vicarious Fear of Crime: Fear for Others and Gendered Social Roles.“ Sociological Forum 21(2): 163-195.

STANKO, Elisabeth A. 1990. Everyday Violence: Women's and Men's Experience of Personal Danger. London: Pandora Press.

TEMELOVÁ, Jana, Jana JÍCHOVÁ, Lucie POSPÍŠILOVÁ a Nina DVOŘÁKOVÁ. 2017. „Urban Social Problems and Marginalized Population in Post-Socialist Transition Societies: Perception of the City Centre of Prague, the Czechia." Urban Affairs Review 53(2): 273-304.

TULLOCH, Marian I. 2004. „Parental Fear of Crime: A Discursive Analysis.“ Journal of Sociology 40(4): 362-377.

VANDERVEEN, Gabry. 2006. Interpreting Fear, Crime, Risk and Unsafety. Disertační práce. Rotterdam: Erasmus Universiteit Rotterdam.

VOZMEDIANO, Laura, César SAN-JUAN, Ana I. VERGARA a Natalia ALONSO-ALBERCA. 2017. „,Watch out, Sweetie': The Impact of Gender and Offence Type on Parents' Altruistic Fear of Crime.“ Sex Roles 77(9-10): 676-686.

WARR, Mark. 1992. „Altruistic Fear of Victimization in Households.“ Social Science Quarterly 73(4): $723-736$.

WARR, Mark a Christopher G. ELLISON. 2000. „Rethinking Social Reactions to Crime: Personal and Altruistic Fear in Family Households.“ American Journal of Sociology 106(3): 551-578.

\section{Poděkování}

Rádi bychom poděkovali svým komunikačním partnerkám za ochotu a otevřenost, se kterou k rozhovorům přistoupily, a současně našim kolegyním Nině Dvořákové, Zuzaně Kopecké, Lucii Pospíšilové, Ivě Křrižkové (Přidalové) a Petře Špačkové za pomoc při hledání komunikačních partnerek a následně při samotném sběru dat. Děkujeme rovněž recenzentkám/recenzentům a editorkám, kteří přispěli k vylepšení textu. 


\section{Autoři}

Robert Osman je sociální geograf působící jako odborný asistent na Geografickém ústavu Masarykovy univerzity a současně jako odborný pracovník v Oddělení environmentální geografie na Ústavu geoniky AV ČR, v.v.i. Mezi jeho hlavní výzkumná témata patři geografie času, rytmicita místa, časoprostorová zkušenost, lidská teritorialita a geografie znevýhodnění. Využívá především kvalitativních výzkumných metod, o jejichž širší etablování v rámci tuzemské geografie se snaží, například zaváděním nových metodických kurzů v rámci Geografického ústavu MU. Editoval knihy Prostor(y) geografie (2014, Karolinum) a Geografie ,okrajem“ (2019, Karolinum).

Kontakt: Př́rodovědecká fakulta Masarykovy univerzity, Geografický ústav, Brno; osman@ mail.muni.cz; Ústav geoniky AV ČR, v. v. i., Brno; robert.osman@ugn.cas.cz; ORCID 0000-0002-1066-7664.

Jana Jíchová je sociální geografka, působí jako vědecká pracovnice na katedře sociální geografie a regionálního rozvoje Přírodovědecké fakulty Univerzity Karlovy, kde je členkou výzkumné skupiny Urbánní a regionální laboratoř. Ve svém výzkumu se věnuje geografii města a osídlení, mezi její hlavní témata dlouhodobě patří kriminalita, percepce bezpečí a nebezpečí a kvalita života. Editovala knihy Sociální prostredí Prahy: Město na prahu 21. století (2017) a Historický atlas obyvatelstva českých zemí (2017).

Kontakt: Př́rodovědecká fakulta Univerzity Karlovy, katedra sociální geografie a regionálního rozvoje, Praha; jana.jichova@natur.cuni.cz; ORCID 0000-0002-6397-3331 